Saba, N., Burns, K. N., Cunningham, N. F., Hebert, C. N. \& Patterson, D. S. P. (1966). J. agric. Sci., Camb. 67, I29.

Seekles, L. (1948). Br. vet. F. 104, 238.

Schultz, L. H. (1968). F. Dairy Sci. 51, 1 133.

Shaw, J. C. (1956). F. Dairy Sci. 39, 402.

Williamson, J. R. \& Krebs, H. A. (I96I). Biochem. J. 80, 540.

\title{
Kale anaemia
}

By J. F. D. Greenhalgh, Rowett Research Institute, Bucksburn, Aberdeen, $A B 2$ g $S B$

The two main types of kale grown in Britain, marrowstem and thousandhead, both belong to the species Brassica oleracea L. Marrowstem is a thick-stemmed plant, $I-I \cdot 5 \mathrm{~m}$ tall, whereas thousandhead has a higher ratio of leaf to stem and is a shorter plant. Kale is sown in late spring and normally harvested from October to February, thousandhead being the more resistant to frost. The crop yields about $50000 \mathrm{~kg}$ green matter per hectare $(7000 \mathrm{~kg}$ dry matter) and is either consumed in situ or cut and carried to housed animals. Cattle are rarely fed on kale alone, but sheep may be; when kale is grazed its consumption is not closely controlled. Kale is grown widely in Britain and north Europe generally, and also in New Zealand.

In the UK, the area devoted to kales increased from 85000 ha in 1946 to a maximum of 160000 ha in 1960 , but has since declined rapidly to 86000 ha in 1966 . This decline is partly due to problems associated with the harvesting of the crop, but may be partly attributable to an increasing incidence of so-called kale poisoning. This condition had been seen previously in Germany when kale production was increased during the Second World War (Rosenburger, 1950).

\section{Field cases of kale anaemia}

Only a brief account will be given here of the clinical signs of the disease as it occurs on farms; a full description has been given by Clegg (1966). The animals most commonly affected are dairy cows. After 2-4 weeks of kale feeding, they show weakness, inappetance and, frequently, haemoglobinuria. Milk yield falls, pulse and respiration rates increase and affected animals may die. The main haematological changes are a fall in haemoglobin concentration, from the normal i $\mathrm{g} / \mathrm{I} / \mathrm{o} \mathrm{ml}$ to less than $3 \mathrm{~g} / 100 \mathrm{ml}$ in some cases, and the appearance of Heinz Ehrlich bodies in the red cells. Clegg (1966) describes the changes found post mortem. Other Brassica species, such as rape, also cause anaemia. The incidence of the condition is unknown. Connold (1952) questioned ninety-four farmers in south-west England about their experience of kale and rape, and reported 'four or five cases of rape poisoning'.

Brassica species are known to cause other disorders, particularly goitre and reproductive disorders (Williams, Hill \& Alderman, I965).

\section{Experimental studies}

Kale anaemia has been studied experimentally in Germany (Steger, Piatkowski, 
Busch \& Püschel, 1964; Piatkowski \& Steger, 1965; Steger, Piatkowski \& Busch, 1965), in Sweden by Grant, Holtenius, Jönsson \& Thorell (1968) and in Britain by Penny, David \& Wright (1964), Williams et al. (1965) and ourselves (Greenhalgh, Sharman \& Aitken, 1969). Fig. I, which is taken from our own work, illustrates the

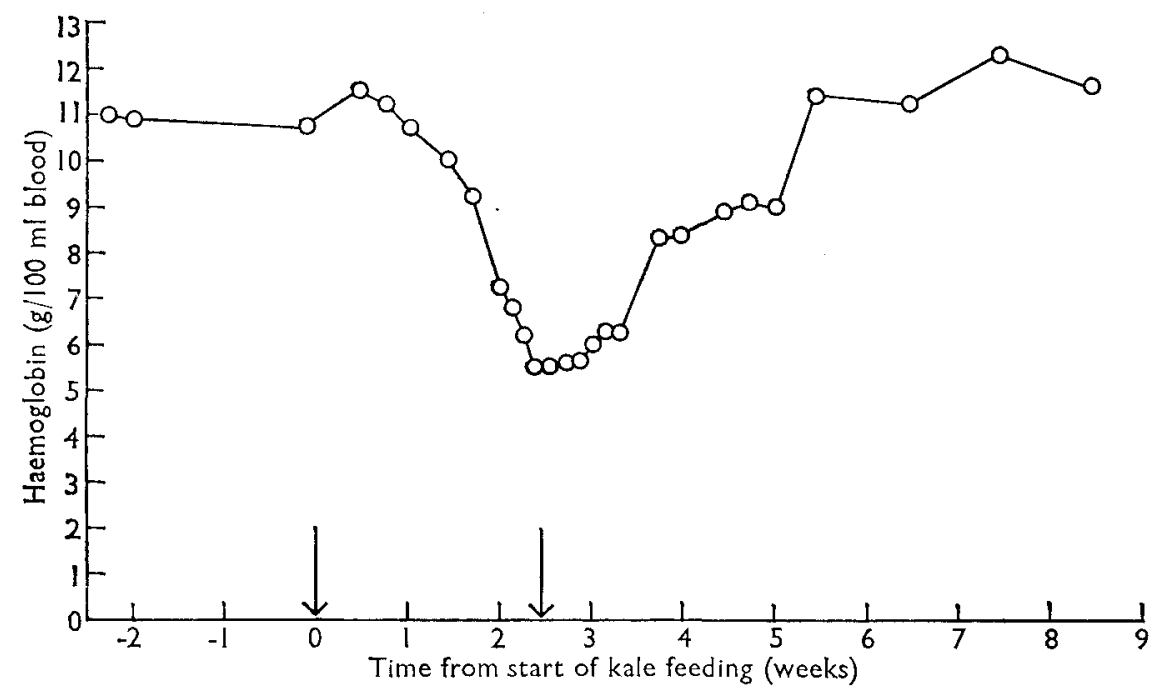

Fig. I. Effect of kale feeding on the blood haemoglobin concentration of cattle (mean values for two steers; start and finish of kale feeding shown by arrows).

haematological changes found when young cattle are fed on a diet of kale alone. This blood picture can be modified in several ways. In lactating cows the anaemia is more severe, probably because lactating animals eat more kale per unit of bodyweight than non-lactating ones. Goats also become severely anaemic when fed on kale. The sheep that we have tested have not been as susceptible to kale anaemia as cattle, but others have found them equally affected. In cattle, if the diet is composed only partly of kale the anaemia takes longer to develop, and is ultimately less severe, than if kale alone is eaten. Rats, rabbits and guinea-pigs do not become anaemic when fed on fresh kale, and my colleague, $\operatorname{Dr} \mathrm{R}$. H. Smith, has found that freezedried kale is not toxic to mice and hamsters.

The effects of the anaemia on the animal are also variable. In cattle, if blood haemoglobin falls below $6 \mathrm{~g} / 100 \mathrm{ml}$, haemoglobinuria is usually seen, and urination may appear to be painful. Cattle may also show the signs reported in field cases, of weakness, inappetence and a marked increase in heart rate. In goats, on the other hand, haemoglobinuria is much less common and penned animals with only $3^{-4} \mathrm{~g}$ haemoglobin per $100 \mathrm{ml}$ blood appear not to be in any way inconvenienced by the anaemia. In most cases blood haemoglobin concentration returns to normal within ${ }^{2-3}$ weeks of the cessation of kale feeding. Even if kale feeding is continued there is a partial recovery.

In the earlier stages of the condition, as haemoglobin concentration (and red cell 
count) falls rapidly, there is an equally marked increase in the proportion of cells containing Heinz bodies. In severe cases, all the cells may contain one or more of these, but methaemoglobin is not found in significant concentrations. Mean cell volume increases, and reticulocytes, siderocytes and basophilic stippling are seen; these changes indicate the destruction of the older erythrocytes and their partial replacement by younger cells.

\section{Possible causes of kale anaemia}

We now know a good deal about the circumstances in which the disease occurs and about the course it takes, but the cause of the disease has not been determined. Earlier investigators (Piatkowski \& Steger, I 965) considered that mineral deficiencies or imbalances might be responsible for the anaemia, but mineral supplements failed to prevent it, and the course of the disease is more consistent with the presence of some toxic substance in kale. The logical way of identifying such a substance is to divide kale into different fractions and to test each for haemolytic activity. This approach is made difficult by the absence of a satisfactory laboratory test for such activity, and so kale fractions have to be prepared in quantities sufficient for the feeding of young goats (the smallest animals known to be susceptible to the disease) for 3-4 weeks. My colleague, Dr N. A. Matheson, has nevertheless prepared such fractions, and in an early trial found haemolytic activity to be confined to the watersoluble moiety of kale (Rowett Research Institute, I969). Unfortunately, further trials of this kind have given less unequivocal results.

The nature of possible haemolysins can be partly deduced from the known constituents of kale, from the biochemical changes brought about in blood and from other features of the disease. Kale is known to contain thiocyanates (c. 100-150 mg/ Ioo $\mathrm{g}$ dry matter; Johnston \& Jones, I966), and thiocyanates have sometimes caused anaemia in man, but we were unable to induce a haemolytic anaemia in a goat by oral administration of thiocyanate. Kale is also rich in nitrate (up to $\mathrm{I} \cdot 5 \% \mathrm{NO}_{3}$; Becker, 1967 ) but the signs of nitrate poisoning in ruminants are methaemoglobinaemia and a rise in haemoglobin concentration (cf. Winter \& Hokanen, 1964). Increasing the nitrate content of the diet of kale-fed cattle (by $\mathrm{I} \% \mathrm{NO}_{3}$ in dry matter) does not appear to exacerbate their anaemia.

An important clue to the cause of kale anaemia is its restriction to ruminants, which suggests that the haemolysin is synthesized or activated by rumen microorganisms, or alternatively, is absorbed from the rumen but destroyed by the greater acidity prevailing in the stomach of monogastric animals. A further possibility, which is discussed below, is that the enzyme systems of the blood of ruminants differ from those of other animals. Dry heat destroys the toxicity of kale (Steger et al. 1965), as does the process of ensilage, but we have found that autoclaved kale ( $120^{\circ}$ for $3^{\circ}$ $\min$ ) is still toxic.

The haematology of kale anaemia is similar to that of some drug-induced anaemias in man (Dacie, I 967 ). The drugs involved are oxidative, and they overcome the protection against oxidation afforded the haemoglobin by reduced glutathione. Reduced glutathione is produced by the system shown below: 


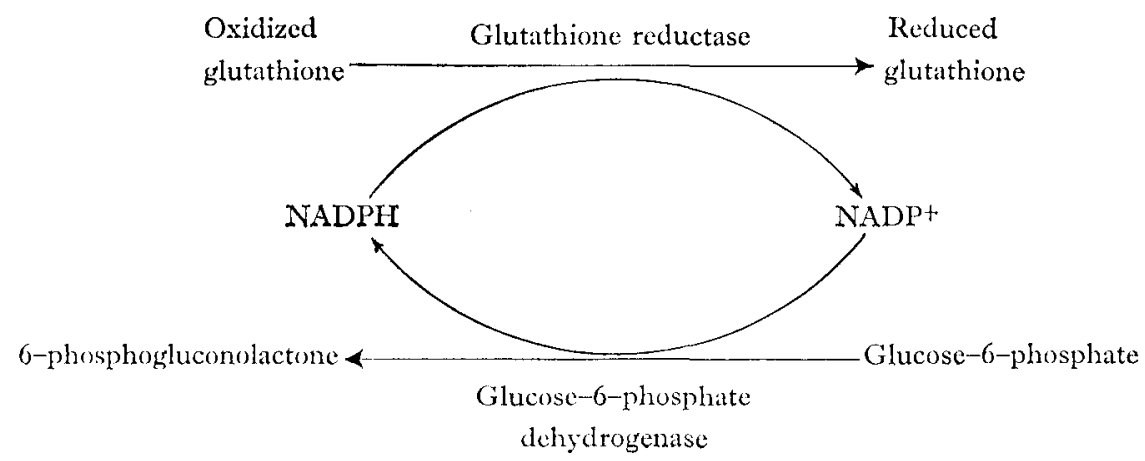

The concentration of reduced glutathione in the erythrocytes of ruminants is similar to that for other animals (Long, I96I) although individual animals may be deficient (Smith \& Osburn, 1967). Cattle erythrocytes, however, appear to have very low levels of glutathione reductase when this is measured in the assay system used for the enzyme in man. In kale anaemia the reduced glutathione concentration of the erythrocytes is depressed but glutathione reductase activity is increased (T. A. J. Prankerd \& C. West, I968, personal communication); the increase in activity of the reductase may reflect a difference between old and young erythrocytes in this respect.

In man, individuals with erythrocytes deficient in glucose-6-phosphate dehydrogenase are susceptible to haemolytic anaemias caused by drugs, particularly the primaquine (antimalaria) drugs. The erythrocytes of sheep and goats have much lower concentrations of glucose-6-phosphate dehydrogenase than other animals (Budtz-Olsen, Axten \& Haigh, 1963); those of cattle are generally normal in this respect, although, as in man, certain individuals may be deficient (Di Domizio, Muscarella \& Minoccheri, 1964). However, we were unable to cause haemolytic anaemia in cattle with oral doses of primaquine $(0.4-5.0 \mathrm{mg}$ primaquine base per $\mathrm{kg}$ live weight per day), and the glucose-6-phosphate dehydrogenase activity of the erythrocytes is not altered in kale anaemia (T. A. J. Prankerd \& C. West, I968, personal communication).

Hydroxylamine, which causes a haemolytic anaemia in man (Martin, Wörner \& Rittmeister, I964) may also cause the condition in ruminants (Jamieson, I958; Winter \& Hokanen, I964; Tillman, Sheriha, Goodrich, Nelson \& Smith, 1965). We recently carried out an experiment with cattle to compare the anaemia produced by hydroxylamine with kale anaemia. Two cattle were given orally $40 \mathrm{mg}$ hydroxylamine hydrochloride per kg live weight per day. Fig. 2 shows that the two conditions have considerable similarities; in addition, animals suffering from hydroxylamine anaemia show increases in the glutathione reductase activity of their erythrocytes ('T. A. J. Prankerd \& C. West, I 968, personal communication).

The fact that kale anaemia can apparently be simulated with hydroxylamine does not, of course, mean that hydroxylamine causes kale anaemia, but this may possibly be so. Nitrate, present in kale in large quantities, is known to be reduced to nitrite 


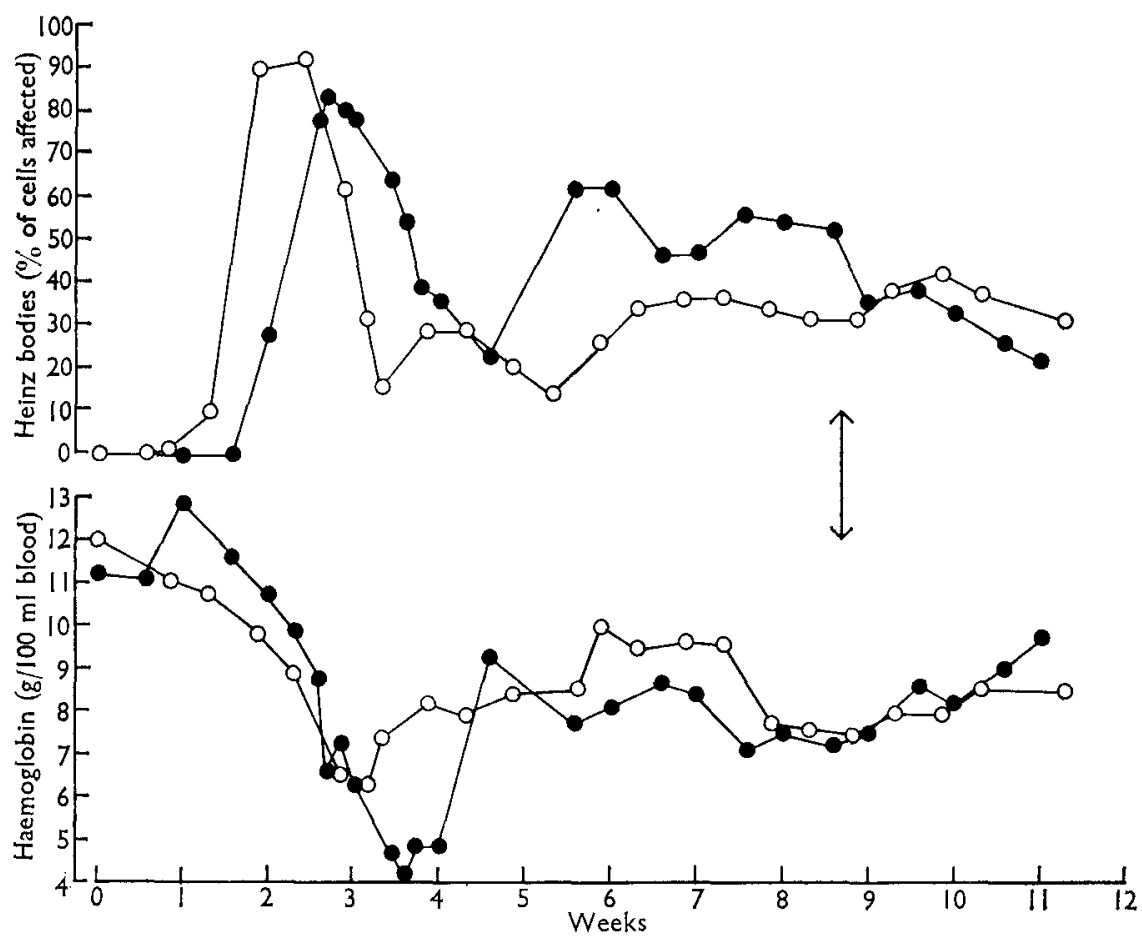

Fig. 2. Heinz body counts and blood haemoglobin concentration in cattle fed on kale alone $(\mathrm{O}-\mathrm{O})$ or fed on hay and concentrates and given orally $40 \mathrm{mg}$ hydroxylamine hydrochloride per kg live weight per day (-) (the arrow marks the point at which the hydroxylamine dose was halved).

in the rumen, and the reduction may conceivably proceed further, to hydroxylamine. Jamieson (1958) found hydroxylamine in the rumen contents of sheep dosed with nitrite.

The experiments on kale anaemia carried out at the Rowett Research Institute involved many members of staff besides myself, particularly Mr G. A. M. Sharman and $\operatorname{Dr}$ N. A. Matheson, whose collaboration I gratefully acknowledge. I also thank Professor T. A. J. Prankerd, of University College Hospital Medical School, and his colleagues, for the blood analyses referred to in the text.

\section{REFERENCES}

Becker, M. (1967). Qualitas Pl. Mater. veg. 15, 48.

Budtz-Olsen, O. E., Axten, B. \& Haigh, S. (1963). Nature, Lond. r98, I ror.

Clegg, F. G. (1966). Proc. int. Tagung der Weltgesellschaft für Buiatrik. Iv. Zurich.

Connold, W. Q. (1952). Agriculture, Lond. 59, I I 3.

Dacie, J. V. (1967). The Haemolytic Anaemias. Vol. 4. London: J. \& A. Churchill.

Di Domizio, G., Muscarella, A. \& Minoccheri, F. (1964). Archo vet. ital. 15, 2 I.

Grant, C. A., Holtenius, P., Jönsson, G. \& Thorell, C. B. (1968). Acta vet. scand. 9, 126. 
Greenhalgh, J. F. D., Sharman, G. A. M. \& Aitken, J. N. (1969). Res. vet. Sci. Io, 64.

Jamieson, N. D. (1958). Nature, Lond. 181, г60г.

Johnston, T. D. \& Jones, D. I. H. (1966). F. Sci. Fd Agric. 17, 7o.

Long, C. (I96r). Biochemists' Handbook, p. 845. London: E. \& F. N. Spon.

Martin, H., Wörner, W. \& Rittmeister, B. (r964). Klin. Wschr. r4, 725.

Penny, R. H. C., David, J. S. E. \& Wright, A. I. (1964). Vet. Rec. 76, 1053.

Piatkowski, B. \& Steger, H. (1965). Arch. Tierernähr. 15, 447.

Rosenburger, G. (1950). Dtsch. tierärtal. Wschr. 57, 330 .

Rowett Research Institute (1969). Rep. Rowett Inst. for 1968, p. 27.

Smith, J. E. \& Osburn, B. I. (I967). Science, N.Y. 158, 374.

Steger, H., Piatkowski, B. \& Busch, B. (1965). Arch. Tierernähr. 15, 455 .

Steger, H., Piatkowski, B., Busch, B. \& Püschel, F. (1964). Arch. Tierernähr. 14, I I 3.

Tillman, A. D., Sheriha, G. M., Goodrich, R. D., Nelson, E. C. \& Smith, G. S. (1965). J. Anim. Sci. 24, 1136.

Williams, H. L., Hill, R. \& Alderman, G. (1965). Br. vet. F. I21, 2.

Winter, A. J. \& Hokanen, J. F. (1964). Am. F. vet. Res. 25, 353.

\section{Endocrine control of calcium and magnesium metabolism in ruminants}

By A. D. CaRe, Rowett Research Institute, Bucksburn, Aberdeen, AB2 $9 S B$

Although the importance of calcium and magnesium homoeostasis has been recognized for many years the precise mechanisms by which this is achieved are still not clearly understood. Over recent years interest in blood calcium regulation has been stimulated by the discovery, isolation and synthesis of calcitonin. Its significance in normal adults, however, remains in some doubt (vide infra). In this paper is outlined our present knowledge of the endocrine factors which help to regulate the control of plasma calcium and magnesium concentration in ruminants through the operation of negative feedback mechanisms. Mention will also be made of those hormones which, although capable of altering the plasma concentrations of either calcium or magnesium, are secreted independently of these concentrations. It will be seen that in many instances the chemical similarity between calcium and magnesium is reflected in hormone effects or in hormone secretion rates. However, this is not always found to be so, e.g. the control of calcitonin secretion appears to be affected in different directions by plasma calcium and magnesium concentrations.

\section{Calcium and magnesium homoeostasis}

It is thought that in adult animals, kept on a diet normal with respect to calcium and vitamin $\mathrm{D}$, an equilibrium exists between bone and blood that is capable of maintaining the plasma calcium at about $70 \%$ of the level usually observed. The remaining $30 \%$ is considered to be under endocrine control. The bulk of this endocrine effect represents the actions of parathyroid hormone with modifying influences imposed by several other hormones. Although the overall ratio of calcium to magnesium in bone is about 50 to $\mathrm{I}$, the ratio of the freely exchangeable fractions of these elements is probably somewhat less but still appreciable. Therefore, endocrine influences which involve changes in bone resorption or accretion rate are likely to have more profound effects on calcium than on magnesium. As far as is known at 